\title{
Effects of Living Mulch and Fertilizer on the Performance of Broccoli in Plasticulture
}

\author{
Nicholas D. Warren ${ }^{1}$ and Richard G. Smith \\ Department of Natural Resources and the Environment, University of New \\ Hampshire, UNH James Hall, Room 114, 56 College Road, Durham, \\ NH 03824
}

\section{Rebecca G. Sideman \\ Department of Biological Sciences, University of New Hampshire, Durham, NH 03824}

Additional index words. intercropping, living mulch, plasticulture, agricultural systems

\begin{abstract}
Living mulch systems allow cover crops to be grown during periods of cash crop production, thereby extending the duration of cover crop growth and associated beneficial agroecosystem services. However, living mulches may also result in agroecosystem disservices such as reduced cash crop yields if the living mulch competes with the crop for limiting resources. We examined whether the effects of an Italian ryegrass [Lolium multiflorum (Lam.) Husnot]-white clover (Trifolium repens L., cv. New Zealand) living mulch on broccoli (Brassica oleracea L. var. italica) yield and yield components were dependent on fertilizer rate in field experiments conducted in Durham, NH, in 2011 (Expt. 1) and 2012 (Expt. 2). Drip-irrigated broccoli was grown under a range of organic fertilizer application rates in beds covered with plastic, with and without a living mulch growing in the uncovered, interbed space. Broccoli yields were similar in the living mulch and bare soil controls under the highest rates of fertilizer application in Expt. 1. In Expt. 2 , living mulch reduced broccoli yields from $28 \%$ to $63 \%$, depending on fertilizer rate. Differences in leaf SPAD values suggest that yield reductions were attributable, in part, to competition for nitrogen; however, other factors likely played a role in determining living mulch effects. Despite yield reductions, the living mulch reduced the prevalence of hollow stem in broccoli in Expt. 1. Organic fertilizer may have inconsistent effects on broccoli yields in living mulch systems.
\end{abstract}

Cover crops provide many beneficial ecosystem services to agricultural production systems, including soil and nutrient retention, resources and habitat for beneficial organisms, and weed suppression (Hartwig and Ammon, 2002). In regions such as northern New England, however, short growing seasons can limit opportunities to establish productive cover crops between cash crop growing periods, particularly in vegetable crop rotations (Snapp et al., 2005). In these cases, living mulch (LM) systems, a form of intercropping that involves growing a cover crop or cover crop mixture simultaneously with a cash crop for part or all of the cropping season, may

\footnotetext{
Received for publication 27 Aug. 2014. Accepted for publication 21 Nov. 2014.

Partial funding was provided by the New Hampshire Agricultural Experiment Station. This is Scientific Contribution Number 2546.

We thank K. Orde, L. Worthen, K. Juntwait, J. Cain, D. Tauriello, and L. Atwood for technical assistance. Additionally, we thank J. McLean and E. Ford at UNH Woodman Research Farm and D. Goudreault and J. Ebba at the UNH MacFarlane Greenhouses for their assistance. Thanks also to J.E. Carroll, F. Pollnac, and J. Wilhelm for their review of a previous version of the manuscript.

${ }^{1}$ To whom reprint requests should be addressed; e-mail Nicholas.Warren@UNH.edu.
}

provide an opportunity to establish cover crops earlier in the growing season and thereby increase the duration of cover crop growth (Teasdale, 1996).

Annual green heading broccoli (Brassica oleracea L. var. italica) is an important freshmarket vegetable crop in the United States with annual production valued at an estimated \$742.6 million in 2011 (USDA NASS, 2012). In New Hampshire and other northern New England states, broccoli is often planted in the summer in raised beds and harvested in the fall. This production schedule means that it can be especially challenging to establish fallsown cover crops in these systems. Furthermore, although the beds on which broccoli is planted are often covered with plastic mulch, the spaces between beds are frequently managed as bare soil through the use of cultivation or herbicides. Thus, growing cover crops as LMs concurrently with broccoli in a plasticulture system may both provide an opportunity to include or expand the use of cover crops in broccoli production systems in short-season regions and reduce the need for soil disturbance in the spaces between beds.

A potential tradeoff of using LMs in broccoli production systems is the possibility of yield reduction resulting from competition from the LM. Reductions in crop yields resulting from LM have been reported for a number of other crops including corn (Faget et al., 2012; Liedgens et al., 2004a, 2004b; Martin et al., 1999), zucchini squash (Walters and Young, 2008), strawberries (Neuweiler et al., 2003), and asparagus (Brainard et al., 2012; Paine et al., 1995). In broccoli LM systems specifically, previous research indicates that the effects of LM on broccoli yields tend to range from neutral to negative. Of the 12 previous broccoli LM studies that we are aware of, only one reported that LM increased mean broccoli head weight (Costello, 1994) and overall marketable yield, although not total yield (Costello and Altieri, 1994).

One study found a consistent reduction in broccoli yield resulting from LM (Chase and Mbuya, 2008), and the other studies reported mixed or no effects of LM on broccoli yields (Brainard and Bellinder, 2004; Ellis et al., 2000; Hooks and Johnson, 2001, 2004; Infante and Morse, 1996; Ponti et al., 2007; Theriault et al., 2009). In contrast, most of the studies reported beneficial effects of the LM on other aspects of agroecosystem performance, including suppression of weeds (Brainard and Bellinder, 2004; Chase and Mbuya, 2008; Infante and Morse, 1996) or insect pests (Bhan et al., 2010; Costello, 1994; Hooks and Johnson, 2001, 2004 2006; Kloen and Altieri, 1990; Ponti et al., 2007). Given these beneficial effects, there is a clear need to identify factors that could improve broccoli yields in LM systems so as to make them more valuable to growers.

Previous broccoli LM studies have examined the effects of LM species, planting date, tillage system, and fertility source; however, we are not aware of any studies that have included multiple rates of fertilizer application as an explicit treatment factor as has been done with some other cruciferous crop LM systems (e.g., Brainard and Bellinder, 2004). Therefore, it remains unknown whether the effects of LM on broccoli yield depend on fertilizer rate and whether competition from the LM could be alleviated through fertility management. Additionally, no research has been conducted on broccoli LM systems under the soil and climate conditions specific to northern New England.

The objective of this study was to assess the performance of irrigated, summer-sown broccoli grown in plasticulture with and without LM under different rates of organic fertilizer application. We hypothesized that LM would reduce broccoli yield in the absence of supplemental fertilization and that competition from a LM could be reduced or eliminated by adjusting fertility rates.

\section{Materials and Methods}

Site description. Two experiments were conducted at the University of New Hampshire (UNH) Woodman Horticultural Research Farm, in Durham, NH (lat. $43^{\circ} 15^{\prime} \mathrm{N}$, long. 70 94' W) in 2011 (Expt. 1) and 2012 (Expt. 2). The two experiments were conducted in separate 0.045 -ha fields to avoid additive effects of LM and broccoli-specific 
pathogens. In both fields, the soil was a Charlton fine sandy loam (Coarse-loamy, mixed, active, mesic Typic Dystrudepts) (NRCS, Soil Survey Staff, 2013). The field used in 2011 had a history of mixed vegetable production and was planted to a cover crop of buckwheat (Fagopyrum esculentum Moench) before the initiation of the study. The field used in 2012 was adjacent to the first field, had a similar cropping history, and had been planted with a cover crop of winter rye (Secale cereale L.) before establishing the experiment.

Experimental design and field management. The experimental sites were rototilled in the spring, 7 (Expt. 1) and 14 (Expt. 2) d before bed formation, to end the cover crops and incorporate residue. After rototilling, raised bed rows were established using a tractor-mounted bed former. Drip tape (8-mm T-Tape; Deere \& Co., Moline, IL) was run along each bed row for subsurface irrigation. Bed rows were then covered with $0.91-\mathrm{m}$-wide white plastic mulch (effective bed row width was $0.56 \mathrm{~m}$ after bed formation). Individual bed rows were spaced on $1.5-\mathrm{m}$ centers, leaving $0.9 \mathrm{~m}$ of bare soil between bed rows. In addition to suppressing weeds on the beds, plastic mulch alters the soil microclimate and improves growing conditions for many vegetable crops, including broccoli (Diaz-Perez, 2009).

Broccoli (cv. Bay Meadows) was seeded on 13 June 2011 (Expt. 1) and 11 May 2012 (Expt. 2) into 72-cell flats in the UNH Macfarlane Greenhouse Facility before the initiation of the field experiments. Seedlings used in Expts. 1 and 2 were transplanted into the field on 6 July 2011 and 7 June 2012, respectively. At transplanting, individual broccoli seedlings were planted on each bed row in single rows into holes cut through the plastic. Along each bed row, individual plants were spaced $30.5 \mathrm{~cm}$ apart (21,858 plants/ha equivalent).

The experimental treatments were applied in a two-factor split-plot design with four replications. The main plot factor was the living mulch treatment, which consisted of either LM planted in the 0.9-m strip of uncovered soil between beds or bare soil (BS). LM and BS treatments were assigned randomly within each block (Fig. 1). The LM was a 1:1 mixture (by seed weight) of Italian ryegrass [Lolium multiflorum (Lam.) Husnot] and white clover (Trifolium repens L., cv. New Zealand), which was drop-seeded between the plastic-covered beds and then incorporated into the soil by raking. In each experiment, the LM was planted the day after the broccoli seedlings were transplanted from the greenhouse to the field. To minimize the potential for light competition, the LM was mowed periodically during the growing season when LM height reached $\approx 20 \mathrm{~cm}$. Consequently, the LM was mowed four times in Expt. 1 and three times in Expt. 2. The seeding rate for the LM was $18.1 \mathrm{~kg} \cdot \mathrm{ha}^{-1}$ in Expt. 1 and $9 \mathrm{~kg} \cdot \mathrm{ha}^{-1}$ in Expt. 2. The lower seeding rate in Expt. 2 was the result of a technical error; however, resulting LM productivity and composition were similar in both years (N. Warren, personal observation). The BS treatments were checked weekly and hand-weeded as needed throughout the growing season to maintain weed-free conditions.

Fertility rate was the subplot factor and included four levels in Expt. 1 and five levels in Expt. 2 (Table 1). Our goal for this treatment was to create a range of fertility rates above and below the recommended rate of $106 \mathrm{~kg}$ nitrogen $(\mathrm{N}) / \mathrm{ha}(1 \times)$, a rate considered optimal for broccoli in our region (Howell and Hazzard, 2012). For each experiment we adjusted the actual applied fertilizer rate based on soil tests that were conducted in each field before treatment establishment so as to account for $\mathrm{N}$ contributed by in situ soil organic matter and the previous season's cover crop. In Expt. 1, in situ soil organic matter was estimated to contribute $22 \mathrm{~kg} \mathrm{~N} / \mathrm{ha}$, whereas in Expt. 2, the contribution of $\mathrm{N}$ from organic matter was estimated at $62 \mathrm{~kg} \mathrm{~N} / \mathrm{ha}$. Thus, to achieve a target $1 \times$ rate of $106 \mathrm{~kg} \mathrm{~N} / \mathrm{ha}$, we had to apply $84 \mathrm{~kg} \mathrm{~N} / \mathrm{ha}$ in Expt. 1, but only $44 \mathrm{~kg}$
$\mathrm{N} /$ ha in Expt. 2 (Table 1). Both experiments included a $0 \times, 1 \times$, and $1.5 \times$ rate, and Expt. 2 included two additional higher fertility rates $(2 \times$ and $2.5 \times)$, whereas Expt. 1 included a $0.5 \times$ rate. The higher target fertility rates were added to Expt. 2 because of the higher in situ $\mathrm{N}$ levels in the field used for that experiment and were intended to achieve applied $\mathrm{N}$ rates that were comparable to and higher than those used in the $1.5 \times$ rate in Expt. 1 (Table 1).

Subplots were bed rows within each LM and BS whole plot and incorporated 17 and 14 broccoli plants in Expts. 1 and 2, respectively. Fertilizer rate treatments were randomly assigned to each subplot within each individual whole-plot replicate (Fig. 1). In both experiments, we used granular PROGRO (5N:3P:4K; North Country Organics, Bradford, VT) to create our fertilizer rate treatment levels. In Expt. 1, all subplots except those assigned to the $0 \times$ treatment

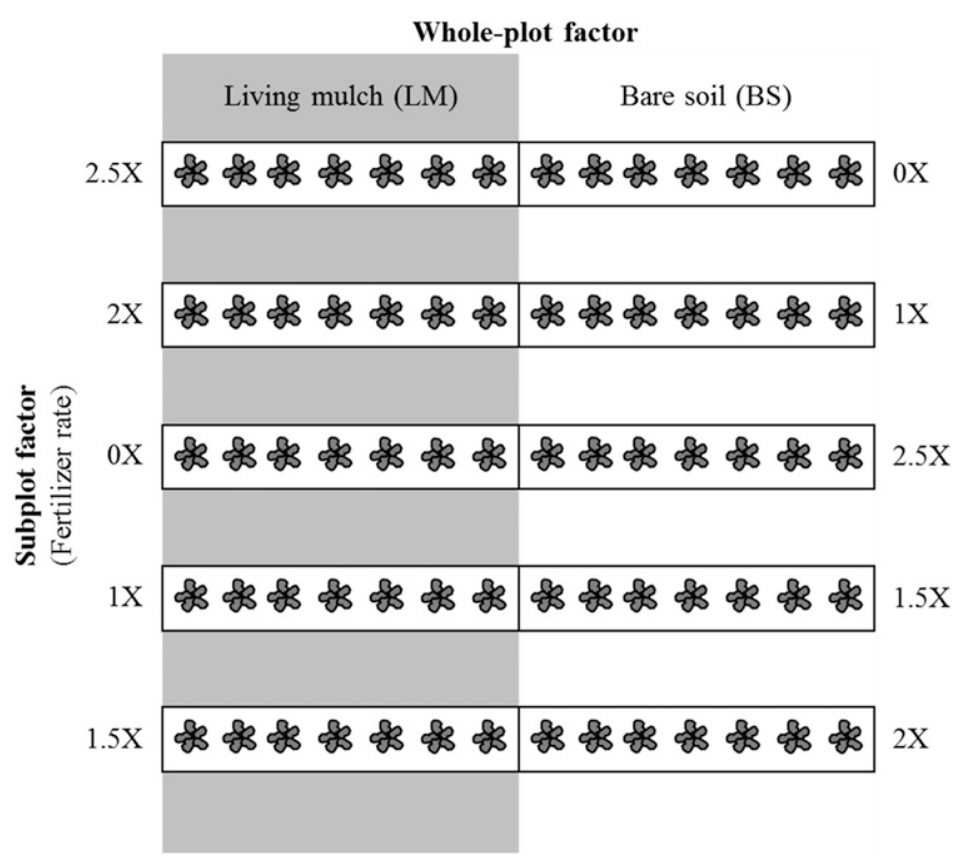

Fig. 1. Schematic representation (overhead view) of the experimental design layout for one of four replicate blocks of the whole-plot (living mulch vs. bare soil) and subplot (fertilizer rate) treatment factors. Subplots were individual raised bed rows covered in white plastic that contained 15 (Expt. 1) and 12 (Expt. 2) broccoli plants. Length of whole-plot along the bed row was $7 \mathrm{~m}$ and $5.8 \mathrm{~m}$ in Expts. 1 and 2 , respectively.

Table 1. Fertility treatment levels in Expts. 1 and 2. ${ }^{2}$

\begin{tabular}{ccccc}
\hline Expt. & Treatment & Estimated soil in situ $\mathrm{N}^{\mathrm{y}}$ & Applied $\mathrm{N}^{\mathrm{y}}$ & Total $^{\mathrm{y}}$ \\
\hline 1 & $0 \times$ & 22 & 0 & 22 \\
& $0.5 \times$ & 22 & 27 & 49 \\
& $1.0 \times^{\mathrm{x}}$ & 22 & 84 & 106 \\
& $1.5 \times$ & 22 & 141 & 164 \\
2 & $0 \times$ & 62 & 0 & 62 \\
& $1.0 \times^{\mathrm{x}}$ & 62 & 44 & 106 \\
& $1.5 \times$ & 62 & 102 & 164 \\
& $2.0 \times$ & 62 & 150 & 212 \\
& $2.5 \times$ & 62 & 202 & 263 \\
\hline
\end{tabular}

${ }^{{ }^{2}}$ Rates of applied $\mathrm{N}$ from commercial organic fertilizer necessary to achieve total $\mathrm{N}$ rates were based on estimated $\mathrm{N}$ available from in situ soil organic matter.

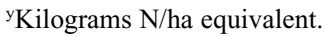

${ }^{\mathrm{x}}$ Recommended $\mathrm{N}$ rate for broccoli from which other fertility treatments were structured.

$\mathrm{N}=$ nitrogen . 
received $24 \mathrm{~kg} \mathrm{~N} /$ ha equivalent of de-hulled soybean meal (6N:1P:1K; Blue Seal, Muscatine, IA), which was banded along bed rows before bed formation; the remainder of the fertility was side-dressed at each plant. Applications of PRO-GRO were evenly split between an application at the time of broccoli transplanting and a side-dressing application that occurred at 3 weeks after transplant in Expt. 1 and 4 weeks after transplant in Expt. 2. At the time of each application, PRO-GRO was applied to each plant individually by incorporating the fertilizer through the holes in the plastic mulch that were created at the time of transplanting. This approach, although time-consuming, and not practical for commercial production systems, ensured that our target rates were consistent and confined to the broccoli root zones.

Organic pesticides were used when necessary to control insect pests over the course of the experiments. Imported cabbageworm (Pieris rapae L.) caused minor damage to broccoli plants in both years and were treated with applications of Bacillus thuringiensis (DiPel; Valent BioSciences, Libertyville, IL). All bed rows were irrigated as needed when soil under the plastic became dry to the touch.

Broccoli yield. Broccoli yield was measured by harvesting mature heads by hand from the inner 15 (Expt. 1) and 12 (Expt. 2) plants in each subplot row. Broccoli plants at the ends of each subplot row served as buffers and were not measured. At each harvest, stems were trimmed to $2.5 \mathrm{~cm}$ below the bottom branch of the head and fresh weight was recorded for each individual plant. Floret size and density were evaluated to determine marketable maturity using a modified grading table (Sorenson and Grevsen, 1994; Theriault et al., 2009). Once the first heads reached a marketable stage, we harvested daily or every other day as broccoli matured and continued until all heads were harvested. The total number of marketable heads, excluding heads that failed to mature or exhibited defects severe enough to prevent marketability, was measured for each plot. Maturity rates were calculated for each harvested broccoli head based on the number of days after transplanting (DAT).

In addition to broccoli yield, we also measured incidence of hollow stem. Hollow stem is a common broccoli physiological disorder characterized by a gap that develops in the center of the stem, which may become discolored thereby reducing quality (Tremblay, 1989). We recorded whether a hollow stem was present or absent in each individual broccoli head in each subplot.

Resource availability. Soil moisture (\% volumetric water content) was measured on two dates in Expt. 1 and four dates Expt. 2 with a handheld probe (FieldScout TDR 300; Spectrum ${ }^{\circledR}$ Technologies, Inc., Aurora, IL) to a depth of $11.5 \mathrm{~cm}$. Measurements were taken before irrigation events both within bed rows (underneath plastic) and between rows (interrows).

Leaf tissue chlorophyll meters can be used to assess $\mathrm{N}$ status in many crops including broccoli (Alcántar et al., 2002). We used a handheld chlorophyll meter (SPAD 502 Plus; Konica Minolta, Spectrum Technologies, Inc. Aurora, IL) to determine leaf chlorophyll values of broccoli in each treatment. SPAD values are useful for comparing relative differences in $\mathrm{N}$ status between treatments; however, without corresponding tissue analysis (which was not performed in this study), they cannot be used as an absolute proxy for $\mathrm{N}$ content. SPAD values were measured on 26 Aug. 2011 (52 DAT) in Expt. 1 by taking two measurements on the newest mature leaf from five individual plants in each subplot. In Expt. 2, SPAD measurements were taken on 12 July (36 DAT) and 17 Aug. (72 DAT) 2012 by taking six measurements on the fifth newest leaf on four individual plants in each subplot.

Weather data for each growing season $(6$ July to 19 Sept. 2011 and 7 June to 16 Aug. 2012) were obtained from UNH's weather station in Durham, NH (except for 3 to 25 Aug. 2011, which were obtained from Weather Underground Inc.). Temperature data were used to calculate growing degree-days (GDD) over the two seasons. The base temperature of $7.2{ }^{\circ} \mathrm{C}$ was selected because it was reported to be the least variable predictor of broccoli maturity rates (Dufault, 1997). Season GDD totals were obtained by summing the daily values, which were calculated using the following formula: GDD = (average daily temperature) - (base temperature $7.2^{\circ} \mathrm{C}$ ).

Statistical analyses. All yield analyses were conducted for each experiment separately by using a model appropriate for a split-plot experimental design. Yield and SPAD data were analyzed with analysis of variance (ANOVA) using a standard least squares regression model with blocking, LM treatment, and fertility as fixed effects. Also included were the interactions between blocking and LM (considered random) and LM and fertility (fixed). If significant effects were detected $(P<0.05)$, Tukey's honestly significant difference test was used for mean comparisons $(P<0.05)$. We assessed the effects of the LM and fertility treatments on plot-to-plot uniformity of broccoli head weight yield by calculating the $\mathrm{CV}$ for each subplot $(\mathrm{n}=4)$. The $\mathrm{CV}$ was calculated using the SD of mean marketable head weight within a subplot divided by the overall mean of the subplot. For hollow stem count data, we used a generalized linear model and a Poisson distribution to fit the main effects of blocking, LM, and fertility. Soil moisture data were analyzed with ANOVA for each time point by block and LM treatment.
Analyses were conducted with $\mathrm{JMP}^{\circledR}$ Pro Version 10.0.0 (SAS Institute Inc., Cary, NC). Data were checked to ensure that they met the assumptions of each test and no transformations were necessary.

\section{Results}

The mean daily temperature was $21{ }^{\circ} \mathrm{C}$ during each of the two experiments. The total number of GDD from transplant to final harvest was slightly higher in Expt. 1 than in Expt. 2 (+30 GDD) (Table 2). Cumulative precipitation between the dates of broccoli transplant to the final harvest was greater in Expt. 1, totaling 241 mm compared with $174 \mathrm{~mm}$ in Expt. 2.

Broccoli yield and yield components. Total marketable broccoli yields across all treatments averaged $3094 \mathrm{~kg} \cdot \mathrm{ha}^{-1}$ in Expt. 1 and $2543 \mathrm{~kg} \cdot \mathrm{ha}^{-1}$ in Expt. 2. In Expt. 1, there was a significant fertility effect and fertility $\times$ LM treatment interaction (fertility: $\mathrm{F}_{3,18}=$ 3.81, $P=0.028$; interaction: $\mathrm{F}_{3,18}=4.49, P=$ 0.016 ) with marketable yields converging at higher fertility levels in the LM and BS treatments. The effect of fertility on marketable yield was not linear; the highest yields were observed below the highest $(1.5 \times)$ fertility level (Fig. 2). In Expt. 2, marketable yields were higher in BS compared with LM $\left(\mathrm{F}_{1,3}=51.96, P=0.006\right)$. The fertility treatment also affected yields (fertility: $\mathrm{F}_{4,24}=$ $8.98, P<0.001)$; however, in contrast to Expt. 1 , there was no interaction between fertility and $\operatorname{LM}(P=0.237)$ (Fig. 2).

In Expt. 1, there was a LM $\times$ fertility interaction for the number of marketable broccoli heads (interaction: $\mathrm{F}_{3,18}=3.26, P=$ 0.046 ) with LM having $21 \%$ fewer marketable heads compared with BS at $0 \times$ and $29 \%$ more than BS at $1.5 \times$. In contrast, the number of marketable heads did not differ among treatments in Expt. $2(P>0.05)$.

Mean marketable fresh head weight was unaffected by LM in Expt. $1(P=0.123)$; however, head weights did increase with increasing fertility and were highest in $1.5 \times$ (fertility: $\mathrm{F}_{3,18}=23.08, P<0.0001$ ). In Expt. 2 , $\mathrm{LM}$ reduced mean head weight by an average of $46 \%$ compared with BS $\left(\mathrm{F}_{1,3}=\right.$ 478.01, $P=0.0002)$. Similar to Expt. 1, head weights in Expt. 2 increased with increasing fertilizer rate (fertility: $\mathrm{F}_{4,24}=11.15, P<$ 0.0001 ) (Fig. 3). There was no LM $\times$ fertility interaction effect on mean head weight in either experiment $(P>0.05)$.

The time until harvestable maturity was unaffected by LM in either experiment

Table 2. Weather data and growing degree-days (GDD, base $7.2^{\circ} \mathrm{C}$ ) for the duration of each growing season (6 July to 19 Sept. 2011 and 7 June to 16 Aug. 2012) in Expts. 1 and 2.

\begin{tabular}{llcrr}
\hline Expt. & Month & Mean temp. $\left({ }^{\circ} \mathrm{C}\right)$ & GDD & Precipitation $(\mathrm{mm})$ \\
\hline Expt. 1 & July & 23 & 413 & 25 \\
$(2011)$ & August & 21 & 433 & 179 \\
& September & 17 & 195 & 37 \\
& Total & & 1,041 & 241 \\
Expt. 2 & June & 19 & 292 & 61 \\
$(2012)$ & July & 22 & 470 & 48 \\
& August & 23 & 250 & 66 \\
& Total & & 1,011 & 174 \\
\hline
\end{tabular}




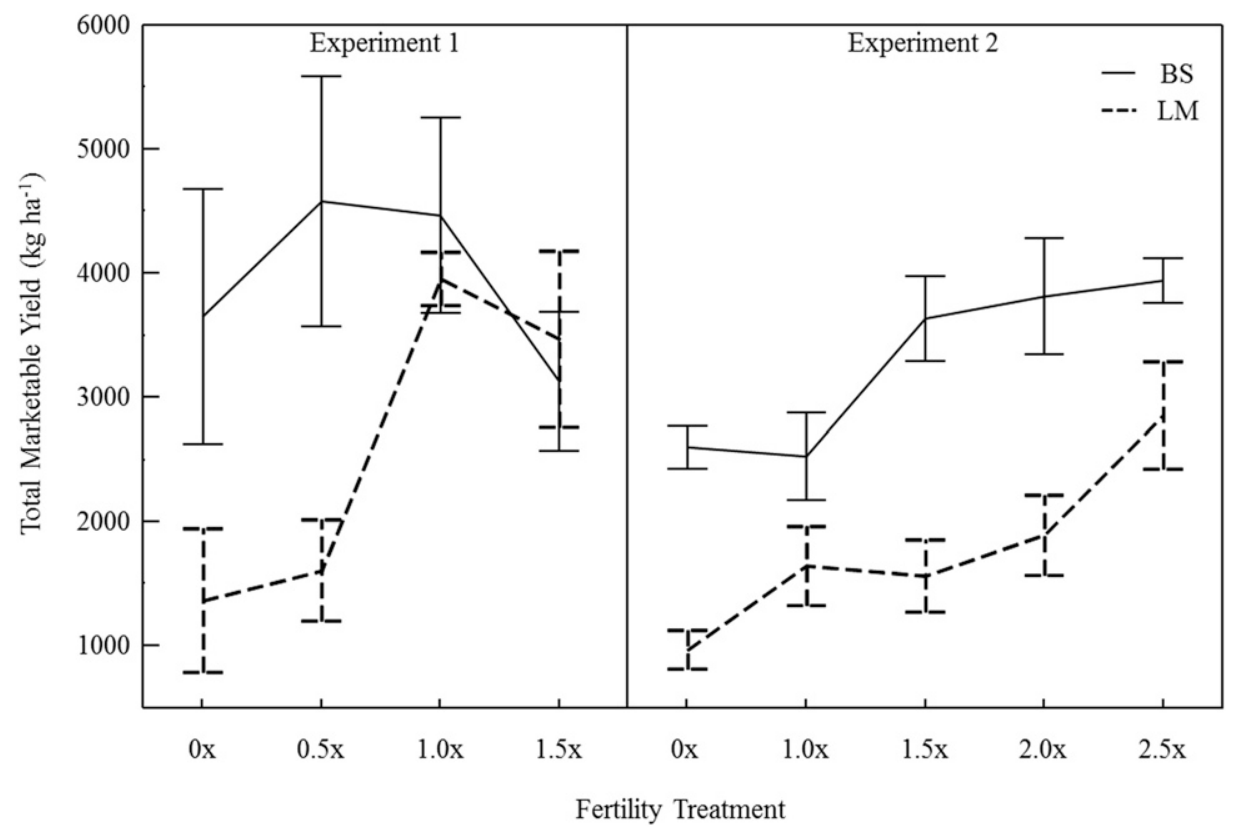

Fig. 2. Total marketable broccoli yield in bare soil (BS) and living mulch (LM) treatments at each nitrogen (N)-based fertility level in Expts. 1 and 2 (see Table 1 for $\mathrm{N}$ rates). Data are means $\pm \mathrm{SE}, \mathrm{n}=4$.

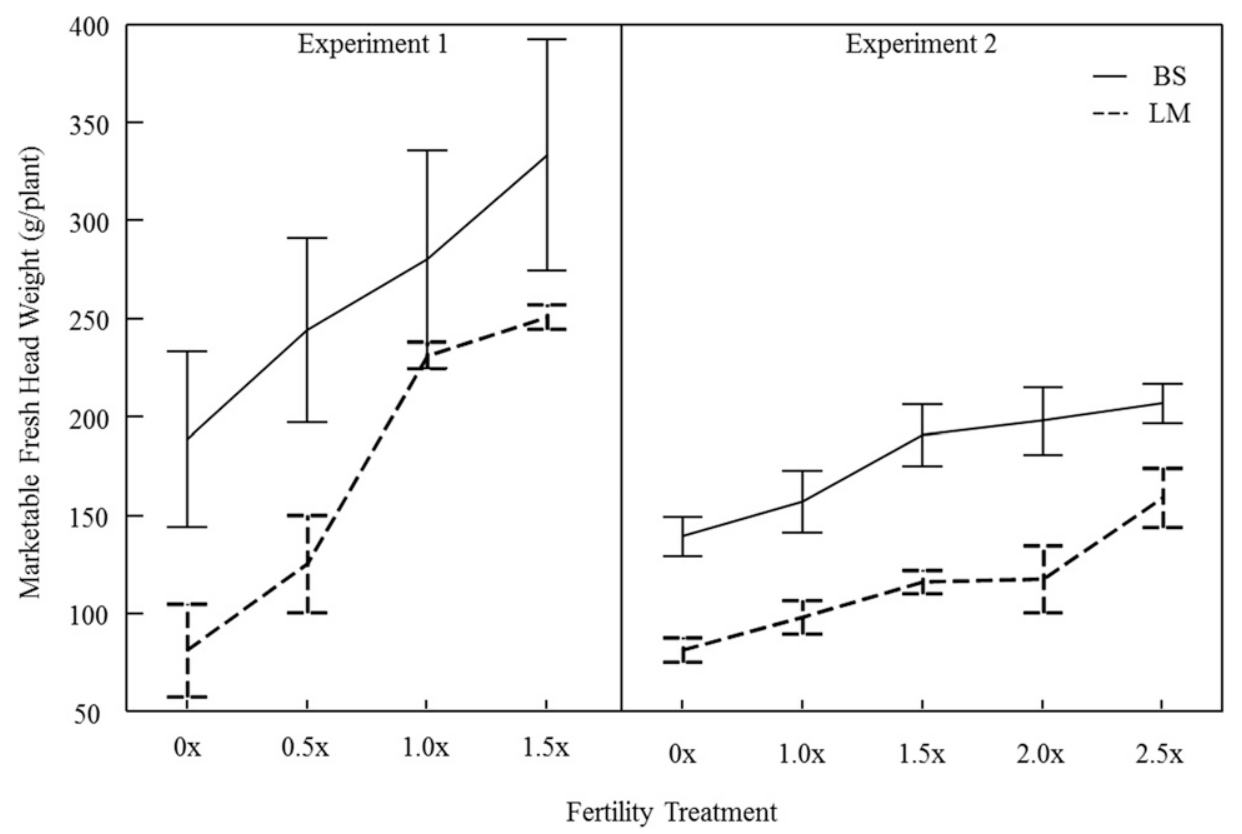

Fig. 3. Effects of living mulch (LM) and bare soil (BS) treatments at different nitrogen (N)-based fertility levels on mean marketable broccoli fresh head weight in Expts. 1 and 2 (see Table 1 for $\mathrm{N}$ rates). Data are means $\pm \mathrm{SE}, \mathrm{n}=4$.

$(P>0.05)$. In contrast, fertility affected maturity rates in both Expts. $1\left(\mathrm{~F}_{3,18}=10.20, P=\right.$ $0.0004)$ and $2\left(\mathrm{~F}_{4,24}=3.63, P=0.019\right)$. In Expts. 1 and 2, broccoli matured $6.3 \%$ and $3.8 \%$ more slowly, respectively, at the $0 \times$ rate compared with the other fertility rates. Interactions between LM and fertility were not significant in either experiment $(P>0.05)$.

Within-plot variability in mean marketable fresh head weight was unaffected by LM in either experiment $(P>0.05)$ but was affected by fertility (Expt. 1: $\mathrm{F}_{3,18}=3.26$, $P=0.047$; Expt. $2: \mathrm{F}_{4,24}=5.10, P=0.0041$ ). In both experiments, head weights tended to be more variable (higher $\mathrm{CV}$ ) at the highest rates of fertility. Interactions between LM and fertility were not significant in either experiment $(P>0.05)$.

In Expt. 1, higher frequencies of hollow stem were observed in BS (mean frequency $0.35 \pm 0.12$ ) compared with LM (mean frequency $0.04 \pm 0.12)\left(\chi^{2} 4.8, \mathrm{df}=1, P=\right.$ $0.027)$. Very little hollow stem was observed in 2012 (less than $2.5 \%$ in BS plots and none in LM) and there were no significant differences between fertility treatments.

Resource availability. Given that bed rows were irrigated with drip tape, we did not expect our LM treatments to lead to moisture limitation. Indeed, for each measurement period, we observed few differences in soil moisture in either the bed row or between rows in LM and BS treatments or as a function of fertility rate in either experiment. In the few instances in which moisture differences did occur, soil moisture was actually higher in the LM treatments (Table 3).

The leaf chlorophyll index did not differ between treatments in Expt. 1 at 52 DAT. In Expt. 2, however, we observed higher SPAD values in the highest fertility levels compared with the lower fertility levels at $35\left(\mathrm{~F}_{4,24}=4.85\right.$, 
$P=0.005)$ and $71\left(\mathrm{~F}_{4,24}=4.48, P=0.008\right)$ DAT. LM treatment effects on SPAD values were significant only in Expt. 2 and only at 71 DAT, the time period coinciding with the final harvest, and were lower in the LM compared with $\mathrm{BS}\left(\mathrm{F}_{1,3}=160.69, P=0.001\right)$ (Fig. 4).

\section{Discussion}

The hypothesis that LM reduces broccoli marketable yield in the absence of fertilizer addition (i.e., at the $0 \times$ fertilizer rate) was supported in both experiments (Figs. 2 and 3). These results are consistent with previous research demonstrating yield reductions in cash crops grown with living mulch intercrops, including in broccoli production systems (Chase and Mbuya, 2008). Not all studies have reported yield reductions resulting from $\mathrm{LM}$, however, and this inconsistency in LM effects among studies likely reflects differences in experimental treatments, LM and cash crop species, and a myriad of other environmental and edaphic factors that vary

Table 3. Soil moisture in living mulch (LM) and bare soil (BS) treatments measured between bed rows (interrow) or within bed rows (before irrigation) in Expt. 1 (2011) and Expt. 2 (2012). ${ }^{z}$

\begin{tabular}{|c|c|c|c|}
\hline \multirow[b]{2}{*}{ Date/position } & \multicolumn{2}{|c|}{$\% \mathrm{VWC}^{\mathrm{y}}$} & \multirow[b]{2}{*}{$P$ value } \\
\hline & Living mulch & Bare soil & \\
\hline \multicolumn{4}{|l|}{ Interrow } \\
\hline 29 July 2011 & 15.2 & 14.7 & 0.6251 \\
\hline 1 Sept. 2011 & 16.8 & 14.1 & 0.0405 \\
\hline 18 June 2012 & 15.5 & 12.0 & 0.0900 \\
\hline 12 July 2012 & 12.6 & 13.2 & 0.6292 \\
\hline 9 Aug. 2012 & 11.2 & 6.8 & 0.0029 \\
\hline 20 Aug. 2012 & 18.8 & 11.6 & 0.0035 \\
\hline \multicolumn{4}{|l|}{ Bed row } \\
\hline 9 Aug. 2012 & 4.0 & 3.6 & 0.4001 \\
\hline 20 Aug. 2012 & 8.7 & 7.0 & 0.1017 \\
\hline
\end{tabular}

${ }^{2}$ Data are means; $\mathrm{n}=4$.

yercent volumetric water content. across cropping systems and sites (Costello, 1994; Hartwig and Ammon, 2002; Kloen and Altieri, 1990; Zemenchik et al., 2000).

The hypothesis that the observed broccoli yield reductions resulting from LM were a consequence of competition for $\mathrm{N}$ was only partially supported by this study. Only Expt. 1 was consistent with broccoli yield reductions in LM being the result of $\mathrm{N}$ limitation, as evidenced by the fact that LM yield reductions were ameliorated by the addition of fertilizer N (Fig. 2). No such patterns were observed in Expt. 2, where LM reduced broccoli yield even at rates that were equivalent to applying $2.5 \times$ higher $\mathrm{N}$ than recommended (Howell and Hazzard, 2012; Vagen et al., 2004; Table 1). Interestingly, chlorophyll content of the broccoli leaves, which we used as a nondestructive measure of plant $\mathrm{N}$ status, differed between the LM and BS treatments only in Expt. 2 and only after harvest (i.e., 72 DAT), although a postharvest SPAD measurement was not taken in Expt. 1. Thus, our indirect measure of plant nutrient status did not reflect the patterns of yield reduction that we observed in the LM treatments in Expt. 1 or in Expt. 2 until after the final harvest had already occurred. Taken together, these results provide little support for the hypothesis that broccoli yield reductions resulting from LM can be attributed solely to competition for $\mathrm{N}$ or ameliorated by increasing organic fertilizer $\mathrm{N}$ rates. Possible explanations for this finding and the relative degree of support for each are discussed below.

The LM may have reduced the availability of resources other than $N$. In addition to soil $\mathrm{N}$, a LM may compete with a cash crop for soil moisture, light, and other soil nutrients (Teasdale, 1996). In our experiments, we attempted to minimize the potential for water and light competition by growing the broccoli on plastic-covered raised beds that were irrigated and by mowing the LM periodically during the growing season. In contrast to what we would expect if the LM was competing for soil moisture, our periodic measurements of volumetric water content within the bed row and directly in the space between rows managed as either LM or BS indicated that the LM did not reduce soil moisture relative to the $\mathrm{BS}$ treatment (Table 3 ). The LM canopy was also separated from the broccoli canopy by a distance of $\approx 0.25 \mathrm{~m}$ (Fig. 1) and was elevated relative to the soil surface between rows. Additionally, the height of the LM was never allowed to exceed $20 \mathrm{~cm}$ so as to restrict the possibility of shading by the LM. Thus, it is unlikely that direct competition by the LM for water and/or light occurred to a degree necessary to explain the patterns observed in this study.

Although lower leaf chlorophyll concentrations are consistent with $\mathrm{N}$ limitation in broccoli (Bowen et al., 1999), in other crops they have also been associated with limitations in other essential soil nutrients such as phosphorus (P) (Sanchez-Rodriguez et al., 2013). Concentrations of $P$ and other nutrients in the soil and broccoli tissue were not measured after treatment establishment; thus, we cannot discount the possibility that the LM reduced the availability of these essential soil nutrients.

The LM may have altered light quality reaching the broccoli, specifically the ratio of red to far-red radiation. Neighboring plants such as those grown as LM can illicit shade avoidance responses in crop plants, well before resource competition occurs (Ballare et al., 1990; Rajcan and Swanton, 2001). These shade avoidance responses, which occur when far-red (FR) light is reflected off the canopy of neighboring plants, may contribute to yield losses by reducing crop growth rate and allocation of resources to reproductive and other structures (Page et al., 2009). For example, Yang et al. (2014) found

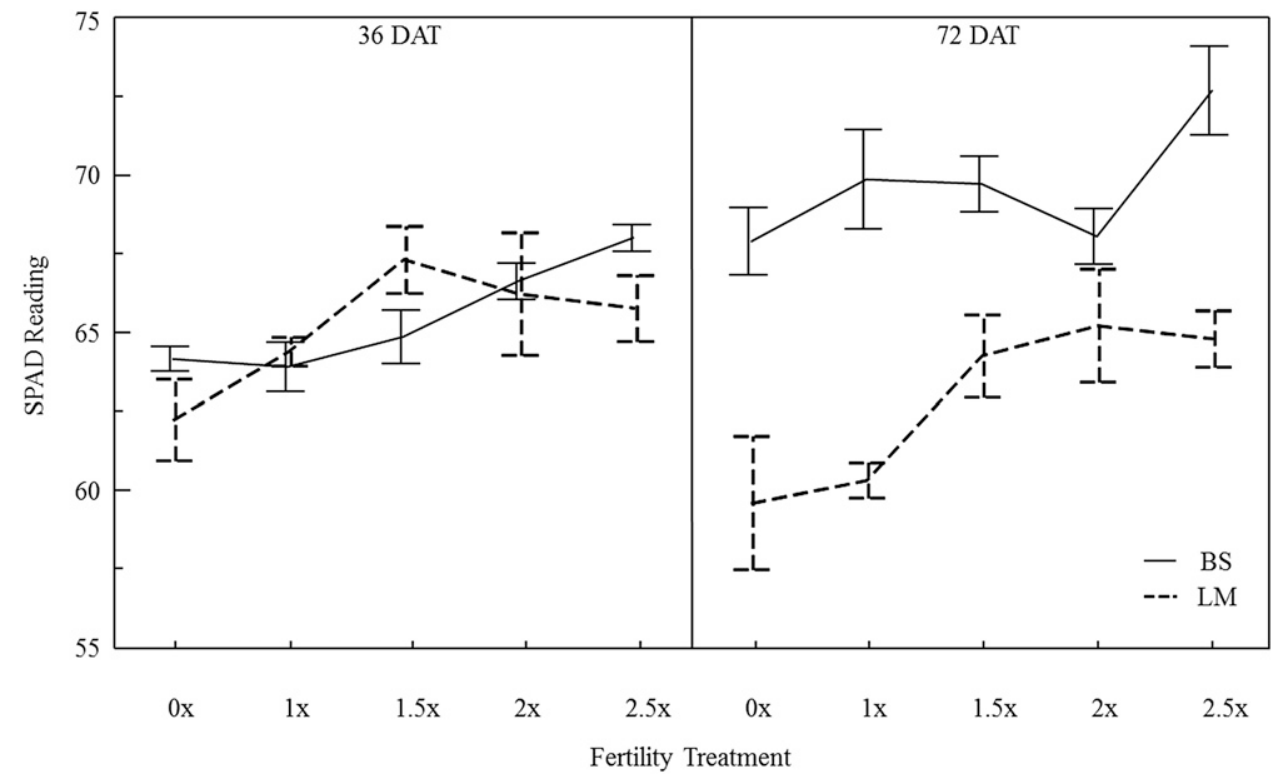

Fig. 4. Broccoli leaf chlorophyll values in living mulch (LM) and bare soil (BS) treatments at different nitrogen (N)-based fertility levels (see Table 1 for rates) in Expt. 2 at 36 and $72 \mathrm{~d}$ after transplanting (DAT). Data are means $\pm \mathrm{sE}, \mathrm{n}=4$. 
that soybean planted adjacent to corn was exposed to light with a lower red (R)/FR ratio than soybean grown in monoculture and this led to reduced soybean seedling above-ground biomass and total root biomass. In our study, the LM likely reflected light with a lower $\mathrm{R} / \mathrm{FR}$ ratio signal than the bare soil, and this could have led to reduced broccoli yields in the LM treatment that may have been independent of or interacted with fertilizer rate. We did not measure the quality of light reaching the broccoli plants in the LM treatment and therefore cannot rule out this possibility as an explanation for our results. Given that the LM was spatially separated from the broccoli as a result of the raised nature of the beds and the use of plastic mulch (Fig. 1), the magnitude of yield loss attributable to the LM is difficult to explain without invoking some form of noncompetitive interference such as changes in reflected light quality.

Effects of LM and fertilizer on broccoli yield may be strongly context-dependent. We observed a $\mathrm{LM} \times$ fertilizer interaction in Expt. 1 but not Expt. 2. This result is difficult to explain. Several factors differed between Expts. 1 and 2, including the cover crop that was present before the initiation of the study, LM seeding rate, quantity of in situ soil organic matter, broccoli transplanting date, and precipitation. Each of these factors could individually (Gaskell and Smith, 2007; Pek et al., 2012; Schonbeck et al., 1993; Sorenson and Grevsen, 1994; Tan et al., 2000) or in combination (Ateh and Doll, 1996; Brainard et al., 2012; Brainard and Bellinder, 2004; Robinson and Dunham, 1954) explain overall yield differences between the two experiments; however, it is unclear how they would affect the nature of the interaction between a LM and fertilizer rate. One possibility is that the degree of root incursion by the LM into the broccoli rhizosphere under the raised bed rows differed between Expts. 1 and 2 as a result of differences in precipitation from 2011 to 2012 and this may have resulted in overall higher rates of competition in Expt. 2 relative to Expt. 1 (Comas et al., 2013; Fageria and Moreira, 2011; Wedderburn et al., 2010). Previous studies have documented the important role that stochastic environmental factors can play in driving crop yield variability in repeated field experiments that are otherwise identical (Schipanski et al., 2014). This suggests that yield outcomes can be strongly context-dependent and with only 2 years of data available in this study, we unfortunately cannot rule out such dependency as an explanation for the results of our study.

Although we observed evidence that LM reduces yield of broccoli, some growers may be willing to accept some level of yield loss given the other potential ecosystem benefits associated with LM systems and other diversified production systems more generally (Letourneau et al., 2011). In production systems in which herbicides are prohibited, maintaining a LM may provide weed suppression benefits and would reduce the need for periodic cultivation during the growing season (Brainard et al., 2012; Brainard and
Bellinder, 2004; Ilnicki and Enache, 1992; Newenhouse and Dana, 1989; Paine et al., 1995; Teasdale and Daughtry, 1993). Reducing tillage can result in improved soil physical and biological properties (Franzluebbers et al., 1999), possibly contributing to improvements in longer-term crop productivity. It is possible that improvements in soil quality associated with reducing tillage, coupled with organic inputs from the LM itself, may reduce the competitive effects often observed between LMs and cash crops over time (Smith et al., 2010).

Our study considered a specific LM, a mixture of Italian ryegrass and clover, and a specific commercial organic fertilizer; therefore, the results reported here may not extend to other species of LM, other LM cash crop systems, or other types of fertilizer. Additional research will be necessary to determine the longer-term effects of LM in broccoli production systems and the role that changes in reflected light quality may play in mediating broccoli yield responses in LM systems.

\section{Literature Cited}

Alcántar, G., M. Sandoval, J.Z. Castellanos, F. Méndez, P. Sánchez, and M. Nieves Rodríguez. 2002. Diagnostic methods to evaluate nutrient status of garlic, onion, and broccoli. Commun. Soil Sci. Plan. 33:2585-2598.

Ateh, C.M. and J.D. Doll. 1996. Spring-planted winter rye (Secale cereale) as a living mulch to control weeds in soybean (Glycine max). Weed Technol. 10:347-353.

Ballare, C.L., A.L. Scopel, and R.A. Sanchez. 1990. Far-red radiation reflected from adjacent leaves - An early signal of competition in plant canopies. Science 247:329-332.

Bhan, M., R. McSorley, and C.A. Chase. 2010. Effect of cropping system complexity on plantparasitic nematodes associated with organically grown vegetables in Florida. Nematropica 40:53-70.

Bowen, P.A., B.J. Zebarth, and P.M.A. Toivonen. 1999. Dynamics of nitrogen and dry-matter partitioning and accumulation in broccoli (Brassica oleracea var. italica) in relation to extractable soil inorganic nitrogen. Can. J. Plant Sci. 79:277-286

Brainard, D.C., J. Bakker, D.C. Noyes, and N. Myers. 2012. Rye living mulch effects on soil moisture and weeds in asparagus. HortScience 47:58-63.

Brainard, D.C. and R.R. Bellinder. 2004. Weed suppression in a broccoli-winter rye intercropping system. Weed Sci. 52:281-290.

Chase, C.A. and O.S. Mbuya. 2008. Greater interference from living mulches than weeds in organic broccoli production. Weed Technol. $22: 280-285$

Comas, L.H., S.R. Becker, V.M.V. Cruz, P.F. Byrne, and D.A. Dierig. 2013. Root traits contributing to plant productivity under drought. Front. Plant Sci. 4:442.

Costello, M.J. 1994. Broccoli growth, yield and level of aphid infestation in leguminous living mulches. Biol. Agr. Hort. 10:207-222.

Costello, M.J. and M.A. Altieri. 1994. Living mulches suppress aphids in broccoli. Calif. Agr. 48:24-28.

Diaz-Perez, J.C. 2009. Root zone temperature, plant growth and yield of broccoli Brassica oleracea (Plenck) var. italica as affected by plastic film mulches. Sci. Hort. 123:156-163.
Dufault, R.J. 1997. Determining heat unit requirements for broccoli harvest in coastal South Carolina. J. Amer. Soc. Hort. Sci. 122:169-174.

Ellis, D.R., K. Guillard, and R.G. Adams. 2000. Purslane as a living mulch in broccoli production. Amer. J. Altern. Agr. 15:50-59.

Fageria, N.K. and A. Moreira. 2011. The role of mineral nutrition on root growth of crop plants, p. 251-331. In: Sparks, D.L. (ed.), Adv. Agron. Vol 110.

Faget, M., M. Liedgens, B. Feil, P. Stamp, and J.M. Herrera. 2012. Root growth of maize in an Italian ryegrass living mulch studied with a non-destructive method. Eur. J. Agron. 36:1-8.

Franzluebbers, A.J., G.W. Langdale, and H.H. Schomberg. 1999. Soil carbon, nitrogen, and aggregation in response to type and frequency of tillage. Soil Sci. Soc. Amer. J. 63:349-355.

Gaskell, M. and R. Smith. 2007. Nitrogen sources for organic vegetable crops. HortTechnology $17: 431-441$.

Hartwig, N.L. and H.U. Ammon. 2002. 50th anniversary-Invited article-Cover crops and living mulches. Weed Sci. 50:688-699.

Hooks, C.R.R. and M.W. Johnson. 2001. Broccoli growth parameters and level of head infestations in simple and mixed plantings: Impact of increased flora diversification. Ann. Appl. Biol. 138:269-280.

Hooks, C.R.R. and M.W. Johnson. 2004. Using undersown clovers as living mulches: Effects on yields, lepidopterous pest infestations, and spider densities in a Hawaiian broccoli agroecosystem. Intl. J. Pest Mgt. 50:115-120.

Hooks, C.R.R. and M.W. Johnson. 2006. Population densities of herbivorous lepidopterans in diverse cruciferous cropping habitats: Effects of mixed cropping and using a living mulch. BioControl 51:485-506.

Howell, J.C. and R.V. Hazzard. 2012. 2012-2013 New England vegetable management guide. Unv. Massachusetts Ext. Veg. Program, Amherst, MA.

Ilnicki, R.D. and A.J. Enache. 1992. Subterranean clover living mulch-An alternative method of weed-control. Agr. Ecosyst. Environ. 40:249264.

Infante, M.L. and R.D. Morse. 1996. Integration of no tillage and overseeded legume living mulches for transplanted broccoli production. HortScience 31:376-380.

Kloen, H. and M.A. Altieri. 1990. Effect of mustard (Brassica hirta) as a non-crop plant on competition and insect pests in broccoli (Brassica oleracea). Crop Prot. 9:90-96.

Letourneau, D.K., I. Armbrecht, B.S. Rivera, J.M. Lerma, E.J. Carmona, M.C. Daza, S. Escobar, V. Galindo, C. Gutierrez, S.D. Lopez, J.L. Mejia, A.M.A. Rangel, J.H. Rangel, L. Rivera, C.A. Saavedra, A.M. Torres, and A.R. Trujillo. 2011. Does plant diversity benefit agroecosystems? A synthetic review. Ecol. Appl. 21:9-21.

Liedgens, M., E. Frossard, and W. Richner. 2004a. Interactions of maize and Italian ryegrass in a living mulch system: (2) Nitrogen and water dynamics. Plant Soil 259:243-258.

Liedgens, M., A. Soldati, and P. Stamp. 2004b. Interactions of maize and Italian ryegrass in a living mulch system: (1) Shoot growth and rooting patterns. Plant Soil 262:191-203.

Martin, R.C., P.R. Greyson, and R. Gordon. 1999. Competition between corn and a living mulch. Can. J. Plant Sci. 79:579-586.

Neuweiler, R., L. Bertschinger, P. Stamp, and B. Feil. 2003. The impact of ground cover management on soil nitrogen levels, parameters of vegetative crop development, yield and fruit quality of strawberries. Eur. J. Hort. Sci. 68:183-191. 
Newenhouse, A.C. and M.N. Dana. 1989. Grass living mulch for strawberries. J. Amer. Soc. Hort. Sci. 114:859-862.

NRCS, Soil Survey Staff. 2013. Web soil survey. Natural Resources Conservation Service, U.S. Department of Agriculture, Washington, D.C.

Page, E.R., M. Tollenaar, E.A. Lee, L. Lukens, and C.J. Swanton. 2009. Does the shade avoidance response contribute to the critical period for weed control in maize (Zea mays)? Weed Res. 49:563-571.

Paine, L., H. Harrison, and A. Newenhouse. 1995. Establishment of asparagus with living mulch. J. Prod. Agr. 8:35-40.

Pek, Z., H. Daood, M.G. Nagyne, M. Berki, M.M. Tothne, A. Nemenyi, and L. Helyes. 2012. Yield and phytochemical compounds of broccoli as affected by temperature, irrigation, and foliar sulfur supplementation. HortScience 47:1646-1652.

Ponti, L., M.A. Altieri, and A.P. Gutierrez. 2007. Effects of crop diversification levels and fertilization regimes on abundance of Brevicoryne brassicae (L.) and its parasitization by Diaeretiella rapae (M'Intosh) in brocolli. Agr. For. Entomol. 9:209-214.

Rajcan, I. and C.J. Swanton. 2001. Understanding maize-weed competition: Resource competition, light quality and the whole plant. Field Crops Res. 71:139-150.

Robinson, R.G. and R.S. Dunham. 1954. Companion crops for weed control in soybeans. Agron. J. 46:278-281.

Sanchez-Rodriguez, A.R., J.C. Canasveras, M.C. del Campillo, V. Barron, and J. Torrent. 2013. Iron chlorosis in field grown olive as affected by phosphorus fertilization. Eur. J. Agron. 51:101107.

Schipanski, M.E., R.G. Smith, T.L.P. Gareau, R. Jabbour, D.B. Lewis, M.E. Barbercheck, D.A. Mortensen, and J.P. Kaye. 2014. Multivariate relationships influencing crop yields during the transition to organic management. Agr. Ecosyst. Environ. 189:119-126.

Schonbeck, M., S. Herbert, R. Degregorio, F. Mangan, K. Guillard, E. Sideman, J. Herbst, and R. Jaye. 1993. Cover cropping systems for brassicas in the northeastern United States. 1. Cover crop and vegetable yields, nutrients and soil-conditions. J. Sustain. Agr. 3:105-132.

Smith, R.G., D.A. Mortensen, and M.R. Ryan. 2010. A new hypothesis for the functional role of diversity in mediating resource pools and weed-crop competition in agroecosystems. Weed Res. 50:37-48.

Snapp, S.S., S.M. Swinton, R. Labarta, D. Mutch, J.R. Black, R. Leep, J. Nyiraneza, and K. O’Neil. 2005. Evaluating cover crops for benefits, costs and performance within cropping system niches. Agron. J. 97:322-332.

Sorenson, L. and K. Grevsen. 1994. Effects of plant spacing on uniformity in broccoli for once-over harvest. Gartenbauwissenschaf. 59:102-105.

Tan, D.K.Y., C.J. Birch, A.H. Wearing, and K.G. Rickert. 2000. Predicting broccoli development. I. Development is predominantly determined by temperature rather than photoperiod. Sci. Hort. 84:227-243.

Teasdale, J.R. 1996. Contribution of cover crops to weed management in sustainable agricultural systems. J. Prod. Agr. 9:475-479.
Teasdale, J.R. and C.S.T. Daughtry. 1993. Weed suppression by live and desiccated hairy vetch (Vicia villosa). Weed Sci. 41:207-212.

Theriault, F., K. Stewart, and P. Seguin. 2009. Use of perennial legumes living mulches and green manures for the fertilization of organic broccoli. Intl. J. Veg. Sci. 15:142-157.

Tremblay, N. 1989. Effect of nitrogen sources and rates on yield and hollow stem development in broccoli. Can. J. Plant Sci. 69:1049-1053.

USDA NASS. 2012. Vegetables 2011 summary. National Agriculture Statistics Service, U.S. Department of Agriculture, Washington, D.C.

Vagen, I.M., A.O. Skjelvag, and H. Bonesmo. 2004. Growth analysis of broccoli in relation to fertilizer nitrogen application. J. Hort. Sci. Biotechnol. 79:484-492.

Walters, S.A. and B.G. Young. 2008. Utility of winter rye living mulch for weed management in zucchini squash production. Weed Technol. 22:724-728.

Wedderburn, M.E., J.R. Crush, W.J. Pengelly, and J.L. Walcroft. 2010. Root growth patterns of perennial ryegrasses under well-watered and drought conditions. New Zeal. J. Agr. Res. 53:377-388.

Yang, F., S. Huang, R.C. Gao, W.G. Liu, T.W. Yong, X.C. Wang, X.L. Wu, and W.Y. Yang. 2014. Growth of soybean seedlings in relay strip intercropping systems in relation to light quantity and red:far-red ratio. Field Crops Res. 155:245-253.

Zemenchik, R.A., K.A. Albrecht, C.M. Boerboom, and J.G. Lauer. 2000. Corn production with kura clover as a living mulch. Agron. J. 92:698-705. 